\title{
ТЕОРЕТИЧНІ ТА МЕТОДОЛОГІЧНІ ПІДХОДИ ДО СТРАТЕГІЇ ІНВЕСТИЦІЙНОЇ ПРИВАБЛИВОСТІ УКРАЇНИ
}

\author{
Дикань О.В., д.е.н., професор, \\ Новак Т.О., магістрант програми ТЕМПУС (УкрДУЗТ)
}

У статті розглянуті сучасні підходи до інвестиційних процесів, щзо відбуваються на Украӥні, надано визначення трансформачії понять «інвестииійна привабливість» та «інвестиційний клімат», проведений їх аналіз та критично проаналізована нормативна база, щчо забезпечує діяльність іноземних та вітчизняних інвесторів в умовах очікуваних фінансово - економічних потрясінь.

Перш за все, для того, щэоб держава мала змогу залучати іноземні інвестииії, їй необхідно мати відповідний інвестиційний імідж, інвестиційну привабливість та інвестиційний клімат

Ключові слова: інвестиційна привабливість, інвестиційний клімат, інвестори, інвестиційний потенціал, економіка, рінансування, стратегія.

\section{ТЕОРЕТИЧЕСКИЕ И МЕТОДОЛОГИЧЕСКИЕ ПОДХОДЫ К СТРАТЕГИИ ИНВЕСТИЦИОННОЙ ПРИВЛЕКАТЕЛЬНОСТИ УКРАИНЫ}

\author{
Дикань О.В., д.э.н., профессор, \\ Новак Т.А., магистрант программы ТЕМПУС (УкрГУЖТ)
}

В статье рассмотрены современные подходы к инвестиционным проиессам, которые происходят на Украине, дано определение трансформации понятий «инвестиционная привлекательность» и «инвестиционный климат», проведенный их анализ и критически проанализирована нормативная база, обеспечивающцая деятельность иностранных и отечественных инвесторов в условиях ожидаемых финансово - экономических потрясений.

Прежде всего, для того, чтобы государство имело возможность привлекать иностранные инвестиции, ему необходимо иметь соответствующий инвестиционный имидж, инвестиционную привлекательность и инвестиционньй климат.

Ключевые слова: инвестиционная привлекательность, инвестиционный климат, инвесторы, инвестиционный потенциал, экономика, финансирование, стратегия.

\section{THEORETICAL AND METHODOLOGICAL APPROACHES TO THE STRATEGY OF INVESTMENT ATTRACTIVENESS OF UKRAINE}

\author{
Dykan O.V., Doctor of Economics, Professor \\ Novak T.A., Master of program TEMPUS (USU RT)
}

The article considers modern approaches to investment processes that occur in Ukraine, defines the transformation of the concepts of "investment attractiveness" and

(C) Дикань О.B., Новак Т.О.
Вісник економіки транспорту і промисловості № 59, 2017 
"investment climate", analyzes them and critically analyzes the regulatory framework that ensures the activity of foreign and domestic investors in the face of expected financial and economic shocks.

First of all, in order for the state to be able to attract foreign investment, it needs to have an appropriate investment image, investment attractiveness and investment climate. It should be emphasized that the state should provide its investor with the most advantageous positioning conditions and guarantee the protection and return of relevant investments.

Keywords: investment attractiveness, investment climate, investors, investment potential, economy, financing, strategy.

Постановка проблеми. На сучасному етапі розвитку світової економіки перед країною, яка відчуває нестачу внутрішніх ресурсів, пов'язану 3 великими витратами на реалізацію програм економічних і соціальних перетворень, як правило, постає проблема дефіциту державного бюджету та платіжного балансу. Одним із шляхів виходу із такої ситуації $є$ зовнішнє фінансування. Разом 3 тим, можливості інвестування в умовах глобальної фінансово - економічної кризи стануть реальними лише завдяки інвестиційно привабливим проектам i програмам.

Перш за все, для того, щоб держава мала змогу залучати іноземні інвестиції, ій необхідно мати відповідний інвестиційний імідж, інвестиційну привабливість та інвестиційний клімат. Треба підкреслити те, що держава повинна надати своїм інвестором найвигідніші умови позиціонування та гарантувати захист та повернення відповідних капіталовкладень.

Тобто необхідна стратегія інвестиційної привабливості базових галузей економіки. Саме стратегія як генеральна програма дій, що визначає пріоритети проблем i ресурси для досягнення мети формування інвестиційної привабливості конкурентно застарілих галузей, безумовно, надасть шанс технологічного «прориву» та успішного позиціонування на вітчизняному та зарубіжному ринках.

Аналіз останніх публікацій. Проблемам іміджу та інвестиційної привабливості країн присвячено велику кількість робіт вчених - економістів та аналітиків, зокрема це публікації: В.Г. Федоренко [1], І.П. Мойсеєнко [2], К.А. Пріба [3], О.Ю. Амосов [4], та багатьох інших. Проте, слід зазначити, що накопичена практика вивчення проблематики щодо аналізу та оцінювання інвестиційної привабливості базових галузей економіки і держави в цілому в українській науковій думці хоча й позначається у збільшенні кількості наукових публікацій, але нажаль характеризується однотипністю підходів. Головна вада існуючих досліджень полягає у відсутності системності, комплексності підходу та передбаченні очікуваних результатів. Крім того, серед вітчизняних досліджень досі не існує єдиної думки не тільки у питаннях того, як аналізувати та оцінювати інвестиційну привабливість, але й у питаннях визначення іiі як економічної категорії.

Вважається за необхідне визначити місце економіки України у світовому рейтингу, надати додаткове наповнення поняттям «інвестиційний клімат» та «інвестиційна привабливість», оцінити їх дієвість та необхідність для нашої держави, проаналізувати найбільш привабливі для потенційного вкладення іноземних та власних інвестицій регіони та галузі економіки та проаналізувати основні нормативні акти, що мають захистити інтереси іноземних та власних інвесторів на території України.

Метою даної статті $\epsilon$ визначення інвестиційної привабливості та інвестиційного клімату України під кутом зору найбільш привабливих 3 економічної та політичної точок зору регіонів нашої

Вісник економіки транспорту і промисловості № 59, 2017 
держави, а також критичний аналіз нормативних актів, що захищають іноземні інвестиції.

Виклад основного матеріалу. Аналізу та оцінці інвестиційного клімату та привабливості України має передувати сучасне визначення зазначених понять.

Інвестиційний клімат країни - це система інвестиційних відносин та реальних дій, які формуються та реалізуються під впливом великої кількості взаємопов'язаних процесів економічного, політичного, соціально-психологічного, інноваційного, інфраструктурного, нормативно-правового, екологічного, кримінального характеру та відображає перелік привабливих регіонів, галузей економіки та сфери послуг. Ці процеси відображають:

- об'єктивно існуючі можливості країни (регіону, галузі, підприємства) до інвестиційної діяльності (характеризується як інвестиційний потенціал);

- рівень очікуваної дохідності та проблемності інвестування в цей об'єкт (характеризується як інвестиційні ризики);

- існуючі інвестиційні процеси в країні (характеризується як інвестиційна активність) .

Отже, інвестиційний клімат країни - система умов інвестиційної діяльності в країні, яка поєднує такі складові, як інвестиційний потенціал, інвестиційні ризики та інвестиційна активність іï регіонів, сфер економічної діяльності, галузей промисловості та сфер послуг, а також окремих підприємств.

Основні категорії інвестиційної діяльності визначаються наступним чином:

- інвестиційна активність об'єкта інвестування - інтенсивність залучення до нього інвестицій;

- інвестиційний потенціал об'єкта інвестування - це об'єктивно існуючі можливості об'єкта конкурувати в умовах ринкових відносин серед інших подібних об'єктів-конкурентів 3 метою залучення інвестицій 3 урахуванням наявних економічних, соціальних та інших передумов, що $є$ важливими для інвестиційної активності даного об'єкта. Тобто йдеться про вузьке значення поняття «інвестиційний потенціал». У широкому сенсі, інвестиційний потенціал - це рівень можливостей залучення інвестицій та рівень соціально-економічного розвитку країни, іiі регіонів, галузей та підприємств, який формується під впливом прямих іноземних та внутрішніх інвестиційних надходжень;

- інвестиційні ризики об'єкта інвестування - умови, за яких можлива неповна або часткова реалізація інвестиційного потенціалу об'єкта інвестування через наявність негативних чинників внутрішнього та зовнішнього впливу.

Інвестиційна привабливість країни це конкурентна позиція та імідж країни у світовому інвестиційному русі капіталів порівняно з іншими країнами, які залежать від рівня інвестиційного потенціалу та інвестиційних ризиків окремих іiі економічних і територіальних складових, тобто динаміки інвестиційного клімату країни.

Отже, інвестиційний клімат об'єкта інвестування (країни, регіону, галузі, підприємства) визначається як його певний стан, а привабливість - це так звана «міміка» об'єкта інвестування, сигнал до інвестора, запрошення до інвестиційної діяльності. Діалектику інвестиційного процесу відображає закон взаємного переходу кількісних змін у якісні; кількісні зміни інвестиційного клімату обумовлюють якісну зміну інвестиційної привабливості, яка у майбутньому може змінити інвестиційний клімат завдяки стрибку - переходу від старої якості до нової. Такий підхід дозволяє розрізняти інвестиційний клімат та інвестиційну привабливість не тільки за змістом, але й за місцем та часом реалізації.

$$
\text { Відносно інвестиційної }
$$

привабливості України можна сказати, що вона має сприятливе інвестиційним потокам географічне положення щодо 
Європи, Центральної Азії і, звичайно, Росії. Транзитне положення України обумовлює досить широке коло можливостей залучення різноманітних інвестицій у виробничу сферу та сферу послуг. Унікальними для інвестування вбачаються агропромисловий, курортно рекреаційний комплекси

безумовно,залізнична галузь. Чорноморські порти, які не замерзають, стимулюють можливості транспортувати вантажі 3 південних до північних країн, із країн Балтії до Чорного моря i далі - до Близького Сходу. Тобто, це якісно новий стимул формування та розвитку міжнародних транспортних коридорів. До цього можна додати наявність сухопутних кордонів із 8 країнами i понад 2700кілометрову берегову лінію. Центральне положення у Європі визначає наявність конкурентних переваг. Таким чином, в Україні доцільно активізувати виробництво як для потреб внутрішнього ринку, так i для цілей експорту в різних напрямках. Зазначене формує подвійні переваги, оскільки існує можливість організації інвестиційно привабливих об'єктів для подальшої реалізації частини продукції в Україні, а іншої - для вивезення за кордон, або надання сервісу транспортних транзитних послуг.

Якщо скласти рейтинг найбільш привабливих регіонів країни, то, безумовно, традиційно перше місце займуть Київ та Київська область завдяки розвиненій інфраструктурі та більш якісним освіті, побутовим і медичним послугам. Дніпропетровська область займатиме друге місце завдяки якості автомобільних шляхів та залізничних колій, гнучкості в установленні заробітної плати та здатності до сприйняття інновацій. Третє місце, 3 урахуванням потужності потенціалу індустрії, що певним чином галузево змінюється, посідатиме Харківська область завдяки потужним промисловим можливостям, традиційним інтеграційним зв'язкам та значному резерву робочої сили і великому потенціалу вищих навчальних закладів. Останнє місце належатиме Херсонській області, де найбільшого розвитку набуває аграрний сектор, куди поки ще свої гроші іноземні та вітчизняні інвестори вкладають зовсім неохоче .

Відносно ж інвестиційного клімату України, виходячи 3 вище наведених критеріїв, можна заключити, що інвестиційний потенціал країни i в майбутньому залишатиметься досить потужним, завдяки тому, що вона має велику кількість підприємств різноманітних галузей, які потребують значного вливання інвестиційного капіталу. Завдяки цьому вони зможуть вийти на якісно нові рівні роботи, залучати нові технології у виробництві того чи іншого виду товарів або послуг. Проте, перед Україною постає дуже велика кількість невирішених проблем, які заважають їй гідно конкурувати з країнами, які також потребують іноземних та внутрішніх інвестицій. Слід відмітити, що Україна не має відповідної нормативної бази, яка змогла б забезпечити захист іноземних та вітчизняних інвесторів. Нажаль не відповідає сучасним вимогам податкова системі держави. В останні роки спостерігається значна політична нестабільність, що значною мірою відлякує потенційних інвесторів.

Отже, все вище зазначене можна ідентифікуватися як інвестиційні ризики та невизначеність, тобто умови за яких неможлива повна реалізація інвестиційного потенціалу України.

Повертаючись до проблем нормативного забезпечення захисту іноземних та вітчизняних інвестицій, слід відмітити, що існують нормативні акти, положення та закони, які регламентують діяльність іноземних інвесторів на території України та захищають їх власність не $є$ дієвими. Вони не гарантують в цілому захист інвестиційних коштів.

Так, закон України «Про інвестиційну діяльність» від 18 вересня 1991 року, ВВР, 1991р., №47, ст. 646

Вісник економіки транспорту і промисловості № 59, 2017 
визначає загальні правові, економічні та соціальні умови інвестиційної діяльності на території України. Він спрямований на забезпечення рівного захисту прав, інтересів і майна суб'єктів інвестиційної діяльності незалежно від форм власності, а також на ефективне інвестування народного господарства України, розвитку міжнародного співробітництва та інтеграції.

Закон України "Про режим іноземного інвестування" зі змінами та доповненнями, внесеними Законом України від 16 липня 1999 року N 997-XIV визначає особливості режиму іноземного інвестування на території України, виходячи 3 цілей, принципів і положень законодавства України.

Проте, чисельні порушення зазначених та інших законодавчих актів свідчить про необхідність прийняття та дотримання більш дієвих нормативних актів, уніфікованих до міжнародних стандартів. Закони, які регламентують діяльність іноземних інвесторів на території України були прийняті ще у 90-х роках. 3 того часу відбулися значні зміни у фінансовому «житті» не тільки України, а i всього світу. Таким чином, нам необхідно удосконалити стару або розробити нову, більш досконалу, нормативну базу для діяльності іноземних та вітчизняних інвесторів на території нашої країни.

Висновки. Україна має потенційну інвестиційну привабливість завдяки вигідному положенню у центрі Свропи. Проте, інвестиційний клімат країни залишається нажаль несприятливим для залучення іноземних та вітчизняних інвестицій. Це, у першу чергу, пов'язано 3 тим, що в країні нестійка політична ситуація, мають місце побоювання з боку капіталовкладників відносно некоректних умов роботи. До негативних обставин слід віднести недостатній рівень захисту права власності, відсутність адаптованої до світових стандартів нормативної бази, яка повинна захистити не тільки інвестора, а i підприємство, що використовує іноземні та вітчизняні інвестиції. Відзначимо також i низький рівень корпоративної культури. Зазначене буде предметом подальших досліджень.

\section{ПЕРЕЛІК ВИКОРИСТАНИХ ДЖЕРЕЛ}

1. Федоренко В.Г. Інвестування: Підручник - 2-ге вид. переробл. і доп. - К.: Алерта, 2013. - 448c. Гаврилюк О.В. Інвестиційний імідж та інвестиційна привабливість України // Фінанси України. - 2012. - №3. - c.79-93.

2. Мойсеєнко І.П. Інвестування: Навч. посіб. - К.: Знання, 2014. - 490с.

3. Пріб К.А. Інвестування: Навч. посібник для дистанційного навчання / За наук. ред. М. Ю. Коденської. - К.: Університет «Україна», 2015. - 259с.

4. Амосов, О. Ю. Формування потенціалу підприємства: організаційний та управлінський аспект / О. Ю. Амосов // Бизнес-Информ. - 2012.- № 12. -С.337341.

5. Данько, M. I. Забезпечення конкурентоспроможності промислових підприємств в умовах міжнародних транспортних коридорів [Текст] / М. I. Данько, В. Л. Дикань, Н.В.Якименко // Харків, УкрДАЗТ, 2008. - 169 с.

6. Носа Н. Роль і місце міжнародних транспортних коридорів у розвитку інфраструктури прикордонного регіону [Текст] / Н. Носа //Регіональна економіка. - 2014. - №4. - С. 116 - 120.

7. Дикань, В. Л. Экономика предприятия. [Текст] / В.Л. Дикань, Е.В. Шраменко, Н.В. Якименко - Харьков: УкрГАЖТ, 2008 - 274 с

8. Григор'єв Г. С. Концептуальний підхід до формування транспортногеографічних кластерів в Україні //Актуальні проблеми економіки. - 2015. №4. - C. $60-64$.

9. Инвестор на все 100 [Электронный ресурс]. - Режим доступа: www.investor100.ru 